\title{
Determination of the Physical and Chemical Properties of the Complex Latosol Soil, Mediterranean, Alluvial and Its Inhibitory Effect on Dog Saliva Bacteria
}

\author{
Sjamsiah $^{1}$, Sappewali ${ }^{2}$, Miftahul Jannah ${ }^{3}$, Andriani Usmann ${ }^{4}$, Nur Annisa B ${ }^{5}$, Arifuddin \\ Ahmad $^{6}$, Mashuri Masri ${ }^{7}$. Indah Islamiah Hasanuddin ${ }^{8}$, Hardiyanti Hamrullah ${ }^{9}$ \\ 1,2,3,4,5,8,9 Departement of Chemistry, Faculty of Science and Technology, Universitas Islam \\ Negeri Alauddin Makassar, Indonesia. 92113 \\ ${ }^{6}$ Departement of Hadith, Faculty of Ushuluddin and Philosophy, Universitas Islam Negeri \\ Alauddin Makassar, Indonesia. 92113 \\ ${ }^{7}$ Departement of Biology, Faculty of Science and Technology, Universitas Islam Negeri \\ Alauddin Makassar, Indonesia. 92113 \\ \{sjamsiah.uca@uin-alauddin.ac.id ${ }^{1}$,wali_ass@yahoo.ac.id²,miftahuljannahfr@gmail.com³, \\ andrianiusmanrs@gmail.com ${ }^{4}$, annisa0369@gmail.com ${ }^{5}$, arifuddin.ahmad@uin-alauddin.ac.id ${ }^{6}$, \\ mashuri.masri@uin-alauddin.ac.id ${ }^{7}$, mrsindah597@gmail.com ${ }^{8}$, hardiyanti.hamrullah.a2@gmail.com $\left.{ }^{9}\right\}$
}

\begin{abstract}
This research is to determine the physical and chemical properties of LatosolComplex soil, Mediterranean and Alluvial. In addition, a resistor power test is conducted soil with liquid soap against dog saliva bacteria using a method of sumuran, is by measuring the diameter of the inhibitory zone. The result of this research is obtained Latosol Complex soil has a $\mathrm{pH}$ of 4-5, dry weight of $0.07 \%-0.09 \%$, water content of $6 \%-7 \%$, and N-total $0.08 \%-0.19 \%$. Mediterranean soil has a $\mathrm{pH}$ of $4.8-5.0$, dry weight of $0.06 \%-0.16 \%$, water content $5.8 \%-6.6 \%$, N-total $0.09 \%-0.2 \%$. Alluvial land has $\mathrm{pH} 6.7-6.9$, weight dry $0.03 \%-0.50 \%$, water content $3.0 \%-3.9 \%$, and $\mathrm{N}$-total $0.6 \%-1.7 \%$. Optimum inhibitory zone of wild dog saliva bacteria was obtained in succession the combination of $10 \%$ Latosol Complex soil with liquid soap is $2.4 \mathrm{~cm}$. Mix 20\% Mediterranean soil with liquid soap is $2.4 \mathrm{~cm}$. Aluvial $60 \%$ with liquid soap is $2.5 \mathrm{~cm}$. At depth of soil is $30 \mathrm{~cm}$ each.
\end{abstract}

Keywords: Alluvial soil, Inhibitory zone, Latosol Complex soil, Mediterranean soil, Well method.

\section{Introduction}

Dogs are one of the animals that are often used as pets by humans. Dogs are the first animals to be tamed and have been lived with humans for more than 10,000 years [1]. In addition, dogs have extraordinary ability to communicate with humans so the role of dogs is still badly needed, such as used as a house guard dog and livestock as well as animals hunter. On the other hand, dogs produce saliva which is dangerous for humans because contains bacteria and viruses that can cause various diseases. One of the bacteria found in dog saliva, Micrococcus sp. that can cause meningitis and bacteremia [2].

Licking or saliva dogs can be cleaned using soil due to deep the soil contains bacteria that produce antimicrobials that can be used for inhibit or kill bacteria that are in dog saliva. The 
results of Hasani that Streptomyces sp. belongs to one type of Actinomycetesmost found on the ground. The presence of Streptomyces sp. in the total microbial population has a relation to the depth of the soil [3].

Bacteria can live in various layers of soil. Land in each areawill have different types, physical and chemical properties. For example, data on a mapthe type of soil in Gowa Regency shows that in the Parangloe District Gowa Regency, the more dominant type of soil is the Latosol Complex soil has a crumb structure until it is lumpy and colored red. Other types of soil in particularin Somba Opu Subdistrict are Alluvial brown land. Soil Alluvial chocolate is soil formed from deposits in the upstream area of the riverthe relief is flat or concave which has a smooth, sandy texture has the nature of fertile soil [4]. Meanwhile, on Pattallassang District has Mediterranean soil types. Soil Mediteran or Alfisol land is land derived from volcanic and rich parent materials will be nutrient [5].

Antimicrobial soils can be added to cleaning products like soap to increase the clean power and effectiveness of the soap. Good soap must have high clean power and remain effective used at different temperatures and hardness of water. One type of soap that is widely used by the public is liquid soap because it is more hygienic and more practical used. Research conducted by Handi showed that liquid soap sterile soil has good antimicrobial work where the concentration is greater sterile soil is used so the antimicrobial working power produced will be better [6].

Based on the description above, this study focuses on determining the physical properties and chemistry of the type of Latosol Complexs, Mediterranean and Alluvial as well as the inhibitory test of combination of these soil with liquid soap against dog saliva bacteria. That method used is the sump method, namely by measuring the inhibition zone.

\section{Material and Methods}

\subsection{Material}

The raw material used in this study is Latosol Complex soil, Mediterranean, and alluvial taken in the area of Gowa Regency in September 2017 and the ingredients used in this study are distilled water $\left(\mathrm{H}_{2} \mathrm{O}\right)$, sulfuric acid $\left(\mathrm{H}_{2} \mathrm{SO}_{4}\right)$ concentrated (Merck), dog saliva, 1 N hydrochloric acid $(\mathrm{HCl})$, perchloric acid ( $\mathrm{HClO} 4)$, acid borate $4 \%$, glutamic acid, ascorbic acid, mixed indicator (BCG: $\mathrm{MM}$ ), label, sodium $40 \%$ hydroxide $(\mathrm{NaOH})$, nutrient agar (NA) media, plate count agar (PCA), media Muller Hinton Agar (MHA), MacConkey Agar (MC) media, whatman filter paper no. 42 , ordinary filter paper, cotton, sodium chloride $(\mathrm{NaCl})$, arabic gum, $50 \%$ citric acid, Alkyl Butyl Sulfonate (ABS), Butylated Hydroxy Toluene (BHT), selenium mixture, lemon fragrance, and sodium lauryl sulfate (SLS).

The tools used are atomic absorption spectrophotometer (AA240FS variant), autoclave, a set of Kjeldahl (Kjeltec TM 2200) tools, laminar air flow (Posco), incubator (ThermoScientifict), centrifuge, sieve shaker mess size 150 (Retsch), shaker (ThermoScientifict), desiccator, analytic balance (Kern ABJ), oven (Memmert), $100 \mathrm{~mL}$ beaker, $500 \mathrm{~mL}$ and $1000 \mathrm{~mL}$, petri dishes, $50 \mathrm{~mL}$ measuring cups, $250 \mathrm{~mL}$ erlenmeyer, $25 \mathrm{~mL}$ measuring flask and $100 \mathrm{~mL}, 25 \mathrm{~mL}$ and $10 \mathrm{~mL}$ scale pipettes, magnetic stirrer, $110^{\circ} \mathrm{C}$ thermometer, micropipette, $0.45 \mu \mathrm{m}$ membrane filter, glass object, mortar and pestle, $\mathrm{pH}$ meter, bunsen, electric stove, crowbar, stopwatch, porcelain cup, test tube, glass funnel, stand, clamp, dropper dropper, shelter, plastic funnel, meter, bucket, marker, ruler, spatula, stirring rod, ose round, sterile sample pots, sterile handscoonds, wire netting and spray bottles. 


\subsection{Method}

\section{Latosol Complex Soil, Aluivial Soil, and Mediterranean Soil Sampling}

The land used was taken in the Parangloe District, Pattalassang District and Somba Opu District, Gowa Regency with a random sampling technique that is taking on several points with variations in depth of $0 \mathrm{~cm}, 30 \mathrm{~cm}$ and $60 \mathrm{~cm}$. Samples taken use a crowbar then put in a plastic bag that has been given label according to depth.

\section{Physical and Chemical Properties}

a. pH Test

$\mathrm{pH}$ measurements were carried out using a $\mathrm{pH}$ meter with a ratio of 1: 5.Measurements were made 3 times and the results were averaged [7].

b. Estimated Dry Weight of Land

The sample suspension with a dilution value of $10-1$ is dried in an oven with temperature $105^{\circ} \mathrm{C}$ for 24 hours to remove water content. After that weighed to find outdry weight [8]. Measurements were made 3 times and the results were averagedeven it.

c. Soil Moisture Estimation

The soil is heated in an oven with a temperature of $105^{\circ} \mathrm{C}$ for 24 hours or its weightconstant. The value of soil moisture is obtained from the percentage of the average loss of soil weightduring heating [9]. Measurements were made 3 times and the results were averagedeven it

d. N-Total analysis (Kjedhal method)

The total $\mathrm{N}$-amount in the soil can be determined using the Kjedhal method.Soil samples were weighed 1.0 gram and 2.2 grams of selenium mixture were added.Then put in a digester flask and add $15 \mathrm{~mL}$ of concentrated $\mathrm{H}_{2} \mathrm{SO}_{4}$ constructed in a heating block for 45 minutes at $380^{\circ} \mathrm{C}$. After that, added $50 \mathrm{~mL}$ of distilled water and put in the Kjeltec tube to be distilled using $40 \% \mathrm{NaOH}$. Destylates are stored in erlenmeyer containing $4 \%$ boric acid $25 \mathrm{~mL}$ andmix indicator $(\mathrm{BCG}+\mathrm{MM})$ then titrated using $0.02 \mathrm{~N} \mathrm{HCl}][10]$.

e. Determination of Base Cation Levels $(\mathrm{K}, \mathrm{Ca}, \mathrm{Mg})$

Soil samples were weighed as much as 3.0 grams, added $25 \mathrm{~mL}$ of distilled water, $5 \mathrm{~mL}$ concentrated nitric acid (HNO 3 ) and boiling rock. Next, the watch glass is closed and heated until the remaining approximately $10 \mathrm{~mL}$. After that, it is cooled and added $5 \mathrm{~mL}$ of HNO 3 concentrated, $1 \mathrm{~mL} \mathrm{HClO} 4$ then heated again until white smoke comes out or the solution becomes clear about 30 minutes. Then cooled and filtered into $100 \mathrm{~mL}$ and crushed using distilled water. Samples were analyzed using a spectrophotometer Atomic Absorption (SSA).

\section{Soil Sterilization}

The soil is dried and then mashed and filtered using filter wirewith mess 150 . The soil is sterilized using an autoclave at $37^{\circ} \mathrm{C}$ for 1 hour.After that, proof is done by scraping the sterilized soil on PCA media [6]. If no more bacteria grows, then the soil hassterile.

\section{Making Liquid Soap}

$100 \mathrm{~mL}$ of aquades were put in a $500 \mathrm{~mL}$ beaker thenheated using an electric stove up to 80 ${ }^{\circ} \mathrm{C}$ (mixture 1). Then insidethe other $400 \mathrm{~mL}$ beaker was added 0.04 grams of Butylated Hydroxy Toluene (BHT) and60 grams of Sodium Lauril Sulfate (SLS) little by little to make it 
easier to homogenize(mix 2). Mixtures 1 and 2 are mixed and homogenized for 30 minutes withstable speed. After that it is cooled to $30^{\circ} \mathrm{C}$ (mixture 3). Then $6 \mathrm{~mL}$ ABS and $2 \mathrm{~mL}$ lemon fragrance are added and homogenized (mixture 4$)$. Afterthat, 4 grams of sodium chloride $(\mathrm{NaCl})$ dissolved with $16 \mathrm{~mL}$ of distilled water in a beaker andput into mixture 4 then homogenized for 5 minutes (mix 5).After that, 4.0 grams of arabic gum are added to mixture 5 little by little andhomogenized for 5 minutes (mix 6 ). Furthermore, $0.2 \mathrm{~mL}$ of $50 \%$ citric acidput in mixture 6 little by little then homogenize for 5 minutes [6].

\section{Making Sterile Soil Liquid Soap}

Making sterile liquid soap is done by mixing liquid soap with sterile soil with multilevel concentration.

\section{Inhibitory Power Test for Sterile Soil, Liquid Soap and Soil Soap Combination against Wild Dog Saliva and Pet Dog Saliva Bacteria}

The bacterial saliva culture of dogs is done by taking a little saliva from the dog using a round ose then scratched on MacConkey Agar and Nutrient Agar media. Then incubated for 24 hours at $37^{\circ} \mathrm{C}$. After that, identification is carried out by conducting Gram staining test of bacteria and observed using a microscope

Making media Muller Hinton Agar (MHA) is done by weighing media as much as 20 grams and dissolved in $500 \mathrm{~mL}$ of distilled water and sterilized using autoclave at $121^{\circ} \mathrm{C}$ for 15 minutes. After that, pour it into a petri dish with thin layer, then wait until it solidifies. After solidifying, installed a collector then the media poured again to cover $2 / 3$ of the blocking section. Waited until it solidified later revoke thieves. Dog saliva bacteria are diluted with a concentration of $1 \mathrm{McF}$. Then applied using sterile cotton bud evenly on the surface of the media Muller Hinton Agar (MHA) which has been made by the well method. After that, the soil is sterile, liquid soap and a combination of soil soap is inserted into the well then incubated at $37^{\circ} \mathrm{C}$ for 24 hours.

\section{Results and Discussion}

\subsection{Soil Physical and Chemical Properties}

The results of the physical and chemical properties test on the three types of soil can be seen in Table 1.

Table 1.The results of the analysis of the test of the physical and chemical properties of soil

\begin{tabular}{ccccc}
\multicolumn{3}{c}{ samples } \\
\hline Type of Soil & Parameters & \multicolumn{3}{c}{ Depth } \\
\cline { 2 - 4 } & & $\mathbf{0} \mathbf{~ c m}$ & $\mathbf{3 0} \mathbf{~ c m}$ & $\mathbf{6 0} \mathbf{~ c m}$ \\
\hline \multirow{4}{*}{ Latosol Complex } & 5,10 & 4,97 & 4,97 \\
& Heavy dry & $0,077 \%$ & $0,093 \%$ & $0,086 \%$ \\
& Water content & $7,26 \%$ & $6,70 \%$ & $7,41 \%$ \\
& N-total & $0,195 \%$ & $0,125 \%$ & $0,085 \%$ \\
& Calcium $(\mathrm{Ca})$ & $1,39 \mathrm{ppm}$ & $1,24 \mathrm{ppm}$ & $1,53 \mathrm{ppm}$ \\
& Potassium $(\mathrm{K})$ & $2,31 \mathrm{ppm}$ & $2,32 \mathrm{ppm}$ & $2,30 \mathrm{ppm}$ \\
& Magnesium $(\mathrm{Mg})$ & $2,91 \mathrm{ppm}$ & $3,46 \mathrm{ppm}$ & $4,40 \mathrm{ppm}$ \\
\hline \multirow{3}{*}{ Alluvial } & $\mathrm{pH}$ & 6,90 & 6,73 & 6,00 \\
& Heavy dry & $0,03 \%$ & $0,50 \%$ & $0,50 \%$ \\
& Water content & $3,90 \%$ & $3,16 \%$ & $3,07 \%$ \\
& N-total & $1,74 \%$ & $0,68 \%$ & $0,60 \%$ \\
\hline
\end{tabular}




\begin{tabular}{ccccc}
\hline \multirow{7}{*}{ Calcium (Ca) } & $8,75 \mathrm{ppm}$ & $8,65 \mathrm{ppm}$ & $8,86 \mathrm{ppm}$ \\
& Potassium (K) & $2,36 \mathrm{ppm}$ & $2,37 \mathrm{ppm}$ & $2,35 \mathrm{ppm}$ \\
& Magnesium $(\mathrm{Mg})$ & $21,1 \mathrm{ppm}$ & $21,3 \mathrm{ppm}$ & $21,7 \mathrm{ppm}$ \\
\hline \multirow{3}{*}{ pH } & 5,03 & 4,90 & 4,83 \\
& Heavy dry & $0,06 \%$ & $0,16 \%$ & $0,11 \%$ \\
& Water content & $6,38 \%$ & $5,58 \%$ & $6,64 \%$ \\
& N-total & $0,28 \%$ & $0,12 \%$ & $0,093 \%$ \\
& Calcium $(\mathrm{Ca})$ & $1,76 \mathrm{ppm}$ & $0,56 \mathrm{ppm}$ & $0,35 \mathrm{ppm}$ \\
& Potassium $(\mathrm{K})$ & $2,27 \mathrm{ppm}$ & $2,19 \mathrm{ppm}$ & $1,68 \mathrm{ppm}$ \\
& Magnesium $(\mathrm{Mg})$ & $6,84 \mathrm{ppm}$ & $7,28 \mathrm{ppm}$ & $11,38 \mathrm{ppm}$ \\
\hline
\end{tabular}

Table 1 shows that the soil $\mathrm{pH}$ of the Latosol and Mediteran complexes tends to be acidic, ie at 4-5. Azizi also suggested that latosol soil has a low $\mathrm{pH}$ level [11]. Alluvial soil $\mathrm{pH}$ values indicate an almost neutral $\mathrm{pH}$ value (Table 1). This can be caused by the land formation area which is near the river flow. Water generally has a neutral $\mathrm{pH}$ so that river water can also affect the land around it or areas along the river flow. The $\mathrm{pH}$ value greatly affects the growth of bacteria or mikroorgaanisme in it, one of which is Actinomycetes which can grow in a $\mathrm{pH}$ range between 6.5-8.0. At $\mathrm{pH}$ below 5, there are only $<1 \%$ Actinomycetes [12].

The values obtained on dry weight and water content indicate that the sample is rather dry soil (Table 1). This indicates that the soil is a poor place for Streptomyces. Members of the Streptomyces genus prefer dry places rather than wet or low water content [13]. Anctinomycetes are more dominant in soil with a humidity of less than $0.98 \%$ [12]. Jiang states that in drier, more barren and colder soils, Streptomyces are more commonly found [14].

Nitrogen levels obtained in Latosol Complex and Mediterranean soil are $0.08 \%-0.28 \%$. This value is classified as very low because basically the nitrogen content in the soil ranges from $0.2 \%-2.0 \%$. According to Azizi Latosol soil has experienced quite intensive destruction resulting in relatively low nutrient content in it [11].. While total N-levels in Alluvial soils are classified as very high [15]. Factors that can cause high levels of nitrogen in alluvial soils are the results of organic matter changes such as from leaves and from plant twigs growing on the soil, so that it can provide nitrogen in the soil.

Table 1 shows very low levels of Latosol Complex and Mediterranean (Ca) soil. Low calcium is caused by several factors including erosion, absorption by plants and leaching. The magnesium $(\mathrm{Mg})$ level is higher with levels of $2.9 \mathrm{ppm}-4.4 \mathrm{ppm}$. Calcium loss is greater than magnesium, caused by colloidal soil materials almost always contain far more calcium than magnesium in a state that can be confused [16]. This is what causes calcium levels lower than magnesium levels. The same results were also obtained by Mulyanto where calcium and magnesium levels in Latosol soil samples are also low, namely calcium 3,34-4,70 $\mathrm{me} \%$ and magnesium 0,99-2,60 me\% [17]. While calcium levels in alluvial soils are higher at $8.75 \mathrm{ppm}$, $8.65 \mathrm{ppm}$, and $8.86 \mathrm{ppm}$ in each layer of soil depth, namely $0 \mathrm{~cm}, 30 \mathrm{~cm}$, and $60 \mathrm{~cm}$.

Potassium levels in the soil are classified as low, namely 1.6-2.3 (Table 1). The level of soil potassium is relatively low, this is caused by the presence of potassium fixation between the lattice or the mineral layer on the soil. In tropical soils the potassium level of the soil can be very low because the parent material is poor in potassium, high rainfall and high temperatures. This high rainfall and temperature accelerates the release or weathering of minerals and washing up K soil [18].

Nutrient content and $\mathrm{pH}$ on the soil can affect the presence of Streptomyces bacteria in the soil. As explained by Hasani that the Streptomyces population in the ecosystem is determined by many physical, chemical and biological factors [3]. The distribution of Streptomyces in water 
and soil depends on pressure, temperature, $\mathrm{pH}$, humidity, salinity, soil texture and climate [19]. Meanwhile, according to Pujiati, Streptomyces is mostly found in drier, more barren and colder soils [20].

\subsection{Sterile Soil Inhibition Test Results, Liquid Soap and a Combination of Soil Soap Against Saliva Bacteria of Wild Dogs}

Dog saliva bacteria were first isolated and then stained with Gram bacteria. The red staining results indicate that the bacterium is a Gram negative bacterium and is in the form of a bacillus. Gram negative bacteria have multilayered cell wall structures consisting of peptidoglycan, lipopolysaccharide and polar outer membranes that are more sensitive to antibacterial compounds that are also polar [15].

The results of isolation of dog saliva bacteria can be seen in Figure 1:

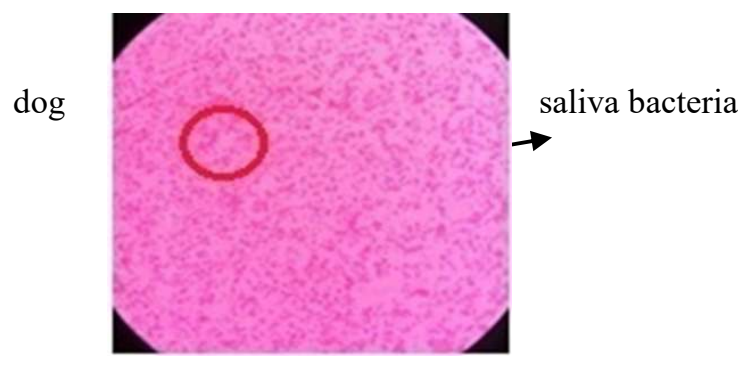

Figure 1. Isolate of Stray Saliva Bacteria

The inhibitory test or antimicrobial activity is carried out by using dilution method by measuring the clear zone or inhibition zone that forms around after the incubation process has been carried out $[21,22]$ The inhibitory test results can be seen in Table 2.

Tabel 2. Sterile Soil Test Results, Combination of Sterile Soil with Liquid Soap against

\begin{tabular}{ccccc}
\multicolumn{5}{c}{ Stray Saliva bacteria } \\
\hline \multirow{2}{*}{ Type of Soil } & Sterile Soil & \multicolumn{3}{c}{ Inhibition Zone at Depth (cm) } \\
\cline { 2 - 5 } & Concentration & $\mathbf{0 ~ c m}$ & $\mathbf{3 0 ~ c m}$ & $\mathbf{6 0} \mathbf{~ c m}$ \\
\hline Latosol Complex & Soil & - & - & - \\
& Liquid soap & 2,5 & 2,4 & 2,5 \\
& Soil soap 10\% & 2,2 & 2,4 & 1,9 \\
& Soil soap 40\% & 2,0 & 2,1 & 2,1 \\
& Positive control & 2,3 & 2,4 & 2,7 \\
\hline Alluvial & Soil & - & - & - \\
& Liquid soap & 2,6 & 2,4 & 2,4 \\
& Soil soap 10\% & 2,4 & 2,3 & 2,5 \\
& Soil soap 40\% & 2,2 & 2,5 & 2,5 \\
& Positive control & 2,4 & 2,5 & 2,7 \\
\hline Mediterranean & Soil & - & - & - \\
& Liquid soap & 2,5 & 2,5 & 2,4 \\
& Soil soap 10\% & 2,3 & 2,3 & 2,2 \\
& Soil soap 40\% & 2,1 & 2,4 & 1,8 \\
& Positive control & 2,6 & 2,6 & 2,5 \\
\hline
\end{tabular}


The results of the analysis show that there is no clear zone or inhibition on the sterilized soil. This shows that there are no active or antibacterial substances that work. The factor that can influence is the storage of samples that are long enough so that the antibacterial substances contained in the soil have been greatly reduced or even gone. In addition, antibacterial substances also have different abilities to inhibit bacterial growth. Gram negative bacteria are more difficult to inhibit than Gram positive bacteria. Gram positive bacteria have simpler cell walls so that antibacterial substances enter the cell more easily and kill the bacteria. While Gram negative bacteria have more complex cell walls, the peptidoglycan layer is thinner than Gram positive bacteria and is surrounded by an outer membrane consisting of lipopolysaccharide and lipoprotein. This is what causes Gram negative bacteria to be more difficult to be disturbed by antimicrobial compounds [23]. However, sterile liquid soap can inhibit bacterial growth in the saliva of wild dogs. This indicates that liquid soap has a good inhibitory power against wild dog saliva. The chemicals contained in liquid soap are proven to eliminate or kill bacteria in the saliva of wild dogs. However, the presence of soil in liquid soap does not provide a clear zone or a larger inhibition zone. This is caused by various factors, including soil samples that are no longer fresh so that the bacteria in them are reduced and antibacterials are not produced when the sterilization process is carried out.

Basically the soil has the ability to remove bacteria. Research conducted by Handi [9] that uses soil in the Ciheuleut area of Baranangsiang Village, Bogor City shows that sterile liquid soap has good antimicrobial power and sterile soil concentrations in liquid soap have a significant influence on the broad clear zone spectrum or in other words increasingly high soil concentration, the wider the clear zone produced. This proves that the soil has the ability to remove bacteria from dog saliva. Factors that influence this are the physical and chemical properties of the soil.

\section{Conclusion}

Based on the results of the study it was concluded that the physical and chemical properties of the Latosol Complex were $\mathrm{pH} 4-5$, dry weight $0.07 \%-0.09 \%$, water content $6 \%-7 \%$, and $\mathrm{N}$ total $0.08 \%-0,19 \%$. Mediterranean soil is $\mathrm{pH} 4.8-5.0$, dry weight is $0.06 \%-0.16 \%$, moisture content is $5.8 \%-6.6 \%$, N-total is $0.09 \%-0.2 \%$. Alluvial soils are $\mathrm{pH} 6,7-6,9$, dry weight is $0,03 \%-0,5 \%$, moisture content is $3.0 \%-3.9 \%$, and $\mathrm{N}$-total is $0.6 \%-1.7 \%$. Complex soil combination Sterile latosol with liquid soap obtained an optimum inhibition zone of $2.4 \mathrm{~cm}$ on a soil depth of $30 \mathrm{~cm}$ with a soil concentration of $10 \%$. The combination of sterile Mediterranean soil with liquid soap obtained an optimum inhibition zone of $2.4 \mathrm{~cm}$ on $30 \mathrm{~cm}$ depth with a soil concentration of $20 \%$ and a combination of sterile alluvial soil with liquid soap obtained an optimum inhibition zone of $2.5 \mathrm{~cm}$ on a soil depth of $30 \mathrm{~cm}$ with a concentration of $60 \%$.

\section{Acknowledgement}

This research was supported by the BOPTN UIN Alauddin Makassar fund. We thank the Ministry of Religion of the Republic of Indonesia and the Alauddin State Islamic University of Makassar for the assistance of funds and facilities provided. 


\section{References}

[1] Heberlein, Merianne T.E., dkk.: A Comparison Between Wolves, Canis lupus, and Dogs, Canis familiaris, in Showing Behaviour towards Humans. Animal Behaviour. pp. 59-66. doi:122 (2016).

[2] Abrahamian, Fredrick M \& Ellie J.C. Goldstein. Microbiology of animal bite wound infection. Clinical Microbiology reviews 24, no. 2. pp. 231-246. Doi 10.1128/ CMR. 00041-10 (2011).

[3] Hasani, Amin, dkk. Streptomycetes: Characteristics and Their Antimikrobial Activities. Advanced Biological and Biomedical Research. 2, no. 1. pp. 63-75 . doi. (2014).

[4] Prasetyo, B.H. dan D. Setyorini. Karakteristik Tanah Sawah Dari Endapan Aluvial dan Pengelolaannya. J. Sumberdaya Lahan 2, no 1. pp.1-14 (2008).

[5] Wijanarko, Andi, dkk. Karakteristik Sifat Kimia dan Fisika Tanah Alfisol di Jawa Timur dan Jawa Tengah. J. Iptek Tanaman Pangan 2, no 2. pp. 214-224. Doi. (2007)

[6] Handi, Abdullah. Tanah Steril dan Sabun Cair Tanah Steril sebagai Bahan Antimikroba terhadap Air Liur Anjing. Skripsi. Bogor: Fakultas Kedokteran Hewan, Institut Pertanian Bogor . https://repository.ipb.ac.id/jspui/bitstream/123456789/50209/1/B08aha1.pdf (2008).

[7] Irfan, Mokhamad. Isolasi dan Enumerasi Bakteri Tanah Gambur di Perkeebunan Kelapa Sawit PT. Tambang Hijau Kecamatan Tambang Kabupaten Kampar. Agroteknologi 5, no 1. pp. 1-8 (2014).

[8] Jannah, Fatah Miftakul. Uji Aktivitas Isolat Actinomycetes dari Tanah Sawah sebagai Penghasil Antibiotik. Naskah Publikasi. Surakarta: Fakultas Farmasi, Universitas Muhammadiyah Surakarta, (2013).

[9] ACIAR.. Laboratorium techniques for plan and Part 2. In Page, A.L., R.H. Miller, and D.R Keeney $(E d s)$. Chemical and microbiological properties. Madison, Wisconsin, USA. pp. 1159 (1990)

[10] USDA,. Soil Survey Laboratory Methods Manual In Burt, R. (ed). Soil Survey Investigation Report. Natural Resources Conservation Service, United States Department of Agriculture, 4,0 no. 4.: pp.167-363, 616-643 (2004).

[11] Azizi, M. Anis. Beberapa Sifat Fisik dan Kimia Tanah Latosol (Oxic Dystropept) Parung yang Disawahkan. Skripsi. Bogor: Fakultas Pertanian, Institut Pertanian Bogor . https://repository.ipb.ac.id/jspui/bitstream/123456789/38820/1/A95MAA.pdf (1995).

[12] Jannah, Fatah Miftakul. Uji Aktivitas Isolat Actinomycetes dari Tanah Sawah sebagai Penghasil Antibiotik. Naskah Publikasi. Surakarta: Fakultas Farmasi, Universitas Muhammadiyah Surakarta, (2013).

[13] Ambarwati, dkk. Aktifitas Antifungi Isolat Streptomyces yang Diisolasi dari Rizosfer Rumput Belulang (Eleusine indica). Ilmu Kefarmasian Indonesia. 13, no. 2.pp.221-228. doi (2016).

[14] Jiang, C.L., and L.H.Xu.. Isolasi methods for study of actinomicetes populasi microbiologi $12 \mathrm{pp}$. 218-220. (1985)

[15] Yamani, Ahmad. Analisis Kadar Hara Makro dalam Tanah pada Tanaman Agroforestri di Desa Tambun Raya Kalimantan Tengah. J. Analisis Kadar Hara 11, no 30 pp. 37-46. doi (2010).

[16] Vesigian, K., \& Roy Kishony, R. Strukrul and Evolution of streptomyces Intraction Networks in Soil and Silico. Plos Biology. 9, no. 10. pp. 1-12 (2011).

[17] Mulyanto, Bagus Sri, dkk. "Analisis Tanah untuk Rekomendasi Pemupukan pada Budidaya Jagung, Padi dan Ketela Pohon”. Sustainable Agriculture. 30, no. 2. pp. 91-96 (2015).

[18] Mulyanto, Bagus Sri. "Kajian Rekomendasi Pemupukan Berbagai Jenis Tanah pada Tanaman Jagung, Padi dan Ketela Pohon di Kabupaten Wonogiri”. Skripsi. Surakarta: Fakultas Pertanian, Universitas Sebelas Maret https://digilib.uns.ac.id/dokumen/detail/29589/Kajian-Rekomendasi-PemupukanBerbagai-Jenis-Tanah-Pada-Tanaman-Jagung-Padi-Dan-Ketela-Pohon-Di-KabupatenWonogiri (2013).

[19] Wang, Y.Zhang, Z. S., Ruan, J., Wang, Y. M ., \& Ali, S. Investigastion of actinomycetes diversity in the tropical rainforest of singapore. J Ind Microbiol ., no. 23 pp.178-187. (1999). 
[20] Pujiati. Isolasi Actinomycetes dari Tanah Kebun sebagai Bahan Petunjuk Praktikum Mikrobiologi". Florea. 1, no. 2. pp. 42-46. (2014).

[21] Young. P.A Brown. M Annie A Dilution Method For The Assay Of Streptomycin. Microbiology 1 pp. 353-360, doi: 10.1099/00221287-1-353. (1947).

[22] Davidson, Charles E., David Estimation Method For Serial Dilution Experiments. Journal Of Microbiological Methods 107. pp. 214-221 (2014).

[23] Faikoh, Elok. Formulasi Sabun Cair Tanah sebagai Penyuci Najis Mughalladzah dengan Variasi Tanah Kaolin dan Bentonit. Skripsi. Jakarta: Fakultas Kedokteran dan Ilmu Kesehatan, http://repository.uinjkt.ac.id/dspace/bitstream/123456789/36295/2/ELOK\%20FAIKOHFKIK.pdf UIN Syarif Hidayatullah (2017). 